\title{
Physiologic Specialization of Puccinia triticina in Canada in 1997
}

\author{
J. A. Kolmer, Cereal Research Centre, Agriculture and Agri-Food Canada, 195 Dafoe Road, Winnipeg, MB, Can- \\ ada R3T $2 \mathrm{M} 9$
}

\begin{abstract}
Kolmer, J. A. 1999. Physiologic specialization of Puccinia triticina in Canada in 1997. Plant Dis. 83:194-197.

In 1997, leaf rust of wheat (Triticum aestivum), caused by Puccinia triticina, was widespread throughout the prairies of western Canada. Warm summer temperatures with frequent dew periods favored spread of the disease in wheat fields in Manitoba, Saskatchewan, and Alberta. The leaf rust epidemic of 1997 was the most widespread and severe in western Canada since 1991. The Canada Prairie Spring wheat cultivars (AC Vista, AC Foremost, AC Crystal) were susceptible to leaf rust, while the bread wheats (AC Domain, AC Barrie, AC Cora, AC Majestic) were more resistant. Forty-seven virulence phenotypes of leaf rust were described in 1997 using 16 near-isogenic differential lines of Thatcher wheat. Phenotypes with virulence to Lr16 comprised $16 \%$ of the isolates in Manitoba and Saskatchewan in 1997. Many recently released Canadian spring wheats have Lrl6 in addition to adult plant resistance genes. Thirty-three isolates also were tested for virulence to plants with adult plant resistance genes $\operatorname{Lr} 12, \operatorname{Lr} 13, \operatorname{Lr} 34$, and Lr13,34. Most isolates were virulent to genes Lr12 and Lr13. All isolates had lower infection types on lines with $L r 34$ compared with the susceptible line Thatcher.
\end{abstract}

Additional keywords: specific resistance, specific virulence, wheat leaf rust

Wheat leaf rust, caused by the fungus Puccinia triticina Eriks. (1), occurs annually throughout the wheat (Triticum aestivum L.) growing regions of Canada. Leaf rust is the most regularly occurring of the three rust diseases of wheat in Canada and throughout the world. Annual national surveys of physiologic specialization of wheat leaf rust have been conducted in Canada since 1931 (9). Virulence to host differential lines or cultivars has been the traditional means of assessing genetic variation in the wheat leaf rust fungus and cereal rust fungi in general. The first host differential set for distinguishing isolates of wheat leaf rust was developed by Mains and Jackson (16), who used 11 wheat cultivars. Three cultivars were later dropped from the set, and the remaining eight cultivars were the differentials used in the International Register of Physiologic Races

Corresponding author: J. A. Kolmer

E-mail: JKOLMER@EM.AGR.CA

Contribution No.1729, Agriculture and AgriFood Canada.

Accepted for publication 17 October 1998.

Publication no. D-1998-1130-01S

This article is in the public domain and not copyrightable. It may be freely reprinted with customary crediting of the source. The American Phytopathological Society, 1999. of $P$. triticina (7). The differentials (Malakoff, Lr1; Webster, Lr2a; Loros, $L r 2 c$; Mediterranean, Lr3; Democrat, Lr3; Hussar, Lr11) were later found to have only a single resistance gene (5) and, in retrospect $(8,9)$, could be considered single gene lines for purposes of virulence phenotype identification. The two other cultivars, Carina and Brevit, had genes Lr2b and $\operatorname{LrB}$. Surveys of virulence variation in the wheat leaf rust fungus, $P$. triticina, were initiated in Canada in 1931 using the International Standard Differentials. Basile (2) proposed removing Carina, Brevit, and Hussar, since these cultivars were more temperature sensitive for infection type. Virulence phenotypes of the leaf rust fungus based on the remaining five cultivars were classified into Unified Numeration (UN) races.

As additional leaf rust resistance genes were isolated and characterized, Dyck and Samborski (5) developed a series of Thatcher wheat lines that were nearisogenic for different leaf rust resistance genes. Differences in infection type due to different cultivar backgrounds or additional resistance genes could be minimized. Samborski and Dyck (18) also developed segregating populations of $P$. triticina and were able to demonstrate gene-for-gene relationships in the wheat leaf rust disease system. By use of the Thatcher lines in the genetic studies and virulence surveys, it became possible to distinguish between isolates that differed for only a single virulence. The annual virulence surveys of $P$. triticina in Canada usually detect 40 to 50 different phenotypes of the fungus based on infection types to 16 of the Thatcher lines $(11,12)$. Virulence phenotype identification is based on infection types on seedling plants. However, a number of important leaf rust resistance genes, such as Lr12, Lr13, Lr22a, Lr34, Lr35, and $L r 37$, are best expressed in the adult plant stage. In recent years, different leaf rust virulence phenotypes in Canada have been routinely assessed for virulence to adult plants with these resistance genes $(10,12)$.

Virulence markers in cereal rust fungi may be highly selected by hosts with the corresponding resistance genes. This can be a complicating factor in evolutionary studies, since leaf rust isolates in two populations may have very similar genetic backgrounds yet may differ for a number of virulences due to the effects of host selection. Virulence markers also may represent only a small portion of the total genetic variation present in leaf rust populations. Nonselective biochemical markers such as isozymes have been used to characterize $P$. triticina populations in North America (4) and Australia $(3,14,17)$. Burdon and Roelfs (4) found variation at only one of 10 isozyme loci in North American isolates of $P$. triticina. Only two isozyme genotypes could be distinguished in a set of 45 isolates of nine different UN virulence phenotypes. Populations of $P$. triticina indigenous to Australia also had little or no isozyme variation (3). Isozymes have not been useful in characterizing $P$. triticina populations in North America since there is so little variation for these markers in the leaf rust fungus.

DNA-based molecular markers such random amplified polymorphic DNA (RAPD) also have been assessed for usefulness in characterizing genetic variation in cereal rust populations. Kolmer et al. (13) used the RAPD technique to characterize variation in a population of $P$. triticina isolates in Canada. Fifteen different molecular phenotypes were distinguished among 37 virulence phenotypes, although most of the RAPD variation was between isolates in the eastern and western Canada populations. Overall, there was little RAPD variation within the two populations compared with the abundant 
virulence variation within each population. Some isolates that differed for virulence phenotype had identical molecular phenotype. Use of a more powerful technique such as amplified fragment length polymorphism (AFLP) may allow molecular differentiation of phenotypes that differ for virulence yet have identical RAPD phenotypes.

Of the different marker systems used to date, virulence to specific resistance genes remains the most effective means to rapidly assess genetic variation in populations of $P$. triticina. Virulence markers are essential in describing $P$. triticina populations since they provide direct information concerning the effects of host selection and potential effectiveness of resistance genes. The annual $P$. triticina virulence survey in Canada is conducted to monitor incidence and severity of leaf rust infections, estimate the relative prevalence and distribution of the predominant virulence phenotypes, and detect new virulence phenotypes that may be virulent to the resistance genes in commonly grown wheat cultivars.

\section{MATERIALS AND METHODS}

Collections of leaf rust were obtained in 1997 as in previous years from Alberta, Saskatchewan, Manitoba, Quebec, and Ontario. Leaf rust collections were obtained from farm fields and uniform wheat nurseries. The collections were increased on seedlings of wheat cultivar Little Club that had been treated with maleic hydrazide to prevent emergence of secondary leaves and to increase the size of uredinia. One week after inoculation, the leaves were trimmed so that only one uredinium remained on each plant. Spores from single uredinium were collected with a cyclone spore collector into a size 00 gelatin capsule when secondary rings had formed around the uredinium. Dustrol (Novartis Canada Ltd., Winnipeg) light industrial oil $(330 \mu \mathrm{l})$ was added to each capsule, and the spore suspensions were atomized onto 1- week-old seedling differential sets composed of 16 near-isogenic lines of Thatcher wheat, each with a different gene for resistance. The 12 differentials in the Prt nomenclature (15) were used along with isogenic lines with $L r B, L r 10, L r 14 a$, and Lr18. After the oil was allowed to evaporate (approximately $1 \mathrm{~h}$ ), the seedling flats were placed in a $100 \%$ humidity chamber for $16 \mathrm{~h}$. All plants were then maintained in a greenhouse between 15 and $25^{\circ} \mathrm{C}$ with supplemental fluorescent lighting. Two to three single uredinial isolates from each collection were evaluated for virulence phenotype. Infection types on the differential sets were read 12 days after inoculation. Each single-uredinial isolate was assigned a three-letter virulence phenotype description based on high or low infection type to the differentials and supplemental lines according to the Prt nomenclature (15). Avirulence-virulence on $\operatorname{LrB}, \operatorname{Lr} 10$, $L r 14 a$, and $L r 18$ was indicated by adding a fourth letter to the Prt virulence code.

Selected P. triticina isolates were tested for virulence to adult plants of Thatcher lines with the adult plant genes $\operatorname{Lr} 12, \operatorname{Lr} 13$, and Lr34, and a line with LrI3 and Lr34. Five plants (one each of Thatcher lines with $\operatorname{Lr} 12, \operatorname{Lr} 13, \operatorname{Lr} 34$, and $\operatorname{Lr} 13,34$, and Thatcher) were grown together to maturity in 15-cm-diameter fiber pots in a greenhouse at 18 to $25^{\circ} \mathrm{C}$ with supplemental fluorescent lighting. Plants were trimmed so that two tillers remained on each plant. The flag leaves of each pot of five plants were inoculated at anthesis with a single isolate by atomizing 2 to $3 \mathrm{mg}$ of urediniospores mixed with oil $(330 \mu \mathrm{l})$. Incubation and growth conditions were the same as for the seedling tests. Infection types were read on the two flag leaves of each plant in the same manner as the seedling infection types 14 days after inoculation.

\section{RESULTS AND DISCUSSION}

Occurrence and severity. In 1997, wheat leaf rust infections were widespread in Manitoba and eastern Saskatchewan.
Heavier than normal leaf rust infections also were reported from western Saskatchewan and Alberta. This was the most widespread and severe leaf rust epidemic in western Canada since 1991. Warm and dry weather during spring and summer facilitated the spread of leaf rust infections throughout the prairie region of western Canada. Plots of susceptible wheats and Canada Prairie Spring (CPS) cultivars AC Foremost, AC Vista, and AC Crystal suffered severe leaf rust infections in Manitoba and eastern Saskatchewan. Based on severity levels, yield losses due to leaf rust in CPS wheats would have ranged from 5 to $20 \%$, with later maturing fields suffering the greatest yield loss. Winter wheat fields in Manitoba and Saskatchewan also suffered severe leaf rust infection. Low levels of leaf rust infection were found in farm fields and plots of bread wheat cultivars AC Domain, AC Cora, Pasqua, and AC Minto. These cultivars did not suffer yield loss due to leaf rust. Moderate levels of leaf rust infections were found on cultivars AC Majestic, Roblin, Glenlea, AC Barrie, Katepwa, AC Taber, and AC Karma.

Physiologic specialization: seedling tests. Three hundred sixty-two singleuredinial isolates were evaluated for virulence phenotype in Canada in 1997 (Table 1). Forty-seven virulence phenotypes in Canada were identified on the 16 Thatcher near-isogenic lines (Table 2). In collections from Quebec and Ontario, over 95\% of isolates had virulence to $L r 1, L r 3$, and Lrlo (Table 1), while less than $5 \%$ of isolates had virulence to $\operatorname{Lr} 9$. Virulence to other resistance genes ranged from 5.2 to $89.5 \%$ in Ontario and Quebec.

In Quebec, 19 virulence phenotypes were identified with MDRJ (19.3\%), MBDS (10.5\%), MBRJ (10.5\%), PBLQ (10.5\%), and TJBJ (10.5\%), the most common phenotypes comprising $61.3 \%$ of the 57 isolates (Table 2). Phenotypes MDRJ and MBDS were also found in 1996 in Quebec (11). Phenotypes MBRJ, MBDS, MDRJ, and TJBJ have all been

Table 1. Number of isolates of Puccinia triticina virulent on 16 lines of Thatcher wheat near-isogenic for leaf rust resistance genes in 1997 in Canada

\begin{tabular}{|c|c|c|c|c|c|c|c|c|c|c|}
\hline \multirow{2}{*}{$\begin{array}{l}\text { Resistance } \\
\text { gene }\end{array}$} & \multicolumn{2}{|c|}{ Quebec } & \multicolumn{2}{|c|}{ Ontario } & \multicolumn{2}{|c|}{ Man/Sask } & \multicolumn{2}{|c|}{ Alberta } & \multicolumn{2}{|c|}{ Total } \\
\hline & No. & $\%$ & No. & $\%$ & No. & $\%$ & No. & $\%$ & No. & $\%$ \\
\hline Lr1 & 55 & 96.5 & 58 & 100.0 & 188 & 98.9 & 55 & 96.5 & 356 & 98.3 \\
\hline $\operatorname{Lr} 2 a$ & 9 & 15.8 & 6 & 10.3 & 33 & 17.4 & 0 & 0 & 48 & 13.3 \\
\hline$L r 2 c$ & 19 & 33.3 & 29 & 50.0 & 33 & 17.4 & 32 & 56.1 & 113 & 31.2 \\
\hline Lr3 & 55 & 96.5 & 57 & 98.3 & 190 & 100.0 & 44 & 77.2 & 346 & 95.6 \\
\hline $\operatorname{Lr} 9$ & 1 & 1.8 & 2 & 3.4 & 0 & 0 & 0 & 0 & 3 & 0.8 \\
\hline Lr16 & 8 & 14.0 & 3 & 5.2 & 31 & 16.3 & 0 & 0 & 42 & 11.6 \\
\hline Lr24 & 21 & 36.8 & 15 & 25.9 & 34 & 17.9 & 5 & 8.8 & 75 & 20.7 \\
\hline Lr26 & 10 & 17.5 & 7 & 12.1 & 27 & 14.2 & 2 & 3.5 & 46 & 12.7 \\
\hline Lr3ka & 33 & 57.9 & 40 & 69.0 & 65 & 34.2 & 10 & 17.5 & 148 & 40.9 \\
\hline Lrl1 & 30 & 52.6 & 29 & 50.0 & 65 & 34.2 & 17 & 29.8 & 141 & 39.0 \\
\hline Lr17 & 9 & 15.8 & 5 & 8.6 & 89 & 46.8 & 21 & 36.8 & 124 & 34.3 \\
\hline Lr30 & 25 & 43.9 & 18 & 31.0 & 62 & 32.6 & 9 & 15.8 & 114 & 31.5 \\
\hline $\operatorname{LrB}$ & 18 & 31.6 & 27 & 46.6 & 90 & 47.4 & 14 & 24.6 & 149 & 41.2 \\
\hline Lr10 & 55 & 96.5 & 58 & 100.0 & 190 & 100.0 & 39 & 68.4 & 342 & 94.5 \\
\hline Lr14a & 51 & 89.5 & 35 & 60.3 & 190 & 100.0 & 27 & 47.4 & 303 & 83.7 \\
\hline $\operatorname{Lr} 18$ & 7 & 12.3 & 3 & 5.2 & 1 & 0.5 & 13 & 22.8 & 24 & 6.6 \\
\hline Total & 57 & & 58 & & 190 & & 57 & & 362 & \\
\hline
\end{tabular}


Table 2. Virulence phenotypes of Puccinia triticina identified on 16 lines of Thatcher wheat near-isogenic for leaf rust resistance genes in 1997 in Canada

\begin{tabular}{|c|c|c|c|c|c|c|c|c|c|c|c|}
\hline \multirow{2}{*}{$\begin{array}{l}\text { Virulence } \\
\text { phenotype }\end{array}$} & \multirow{2}{*}{$\begin{array}{l}\text { Virulence combination } \\
\text { (ineffective } \boldsymbol{L} r \text { genes) }\end{array}$} & \multicolumn{2}{|c|}{ Quebec } & \multicolumn{2}{|c|}{ Ontario } & \multicolumn{2}{|c|}{ Man/Sask } & \multicolumn{2}{|c|}{ Alberta } & \multicolumn{2}{|c|}{ Total } \\
\hline & & No. & $\%$ & No. & $\%$ & No. & $\%$ & No. & $\%$ & No. & $\%$ \\
\hline $\mathrm{CCDJ}$ & $3,26,17,10,14 a$ & 0 & 0 & 0 & 0 & 0 & 0 & 2 & 3.5 & 2 & 0.6 \\
\hline DBBN & $2 \mathrm{c}, \mathrm{B}, 14 \mathrm{a}$ & 1 & 1.8 & 0 & 0 & 0 & 0 & 0 & 0 & 1 & 0.3 \\
\hline FCMT & $2 \mathrm{c}, 3,26,3 \mathrm{ka}, 30, \mathrm{~B}, 10,14 \mathrm{a}, 18$ & 1 & 1.8 & 0 & 0 & 0 & 0 & 0 & 0 & 1 & 0.3 \\
\hline KDMT & $2 \mathrm{a}, 2 \mathrm{c}, 3,24,3 \mathrm{ka}, 30, \mathrm{~B}, 10,14 \mathrm{a}, 18$ & 0 & 0 & 0 & 0 & 1 & 0.5 & 0 & 0 & 1 & 0.3 \\
\hline KFBJ & $2 \mathrm{a}, 2 \mathrm{c}, 3,24,26,10,14 \mathrm{a}$ & 0 & 0 & 0 & 0 & 1 & 0.5 & 0 & 0 & 1 & 0.3 \\
\hline LCBK & $1,26,10,14 a, 18$ & 1 & 1.8 & 0 & 0 & 0 & 0 & 0 & 0 & 1 & 0.3 \\
\hline MBBJ & $1,3,10,14 \mathrm{a}$ & 0 & 0 & 1 & 1.7 & 0 & 0 & 3 & 5.3 & 4 & 1.1 \\
\hline MBDJ & $1,3,17,10,14 \mathrm{a}$ & 0 & 0 & 1 & 1.7 & 0 & 0 & 0 & 0 & 1 & 0.3 \\
\hline MBDS & $1,3,17, \mathrm{~B}, 10,14 \mathrm{a}$ & 6 & 10.5 & 3 & 5.2 & 73 & 38.4 & 1 & 1.8 & 83 & 22.9 \\
\hline MBGJ & $1,3,11,10,14 \mathrm{a}$ & 1 & 1.8 & 4 & 6.9 & 0 & 0 & 8 & 14.0 & 13 & 3.6 \\
\hline MBGK & $1,3,11,10,14 \mathrm{a}, 18$ & 3 & 5.3 & 0 & 0 & 0 & 0 & 0 & 0 & 3 & 0.8 \\
\hline MBQJ & $1,3,3 \mathrm{ka}, 11,10,14 \mathrm{a}$ & 2 & 3.5 & 3 & 5.2 & 1 & 0.5 & 1 & 1.8 & 7 & 1.9 \\
\hline MBRJ & $1,3,3 \mathrm{ka}, 11,30,10,14 \mathrm{a}$ & 6 & 10.5 & 3 & 5.2 & 38 & 20.0 & 5 & 8.8 & 52 & 14.4 \\
\hline MBRK & $1,3,3 \mathrm{ka}, 11,30,10,14 \mathrm{a}, 18$ & 2 & 3.5 & 0 & 0 & 0 & 0 & 0 & 0 & 2 & 0.6 \\
\hline MBRS & $1,3,3 \mathrm{ka}, 11,30, \mathrm{~B}, 10,14 \mathrm{a}$ & 0 & 0 & 0 & 0 & 1 & 0.5 & 0 & 0 & 1 & 0.3 \\
\hline MCDS & $1,3,26,17, \mathrm{~B}, 10,14 \mathrm{a}$ & 2 & 3.5 & 1 & 1.7 & 15 & 7.9 & 0 & 0 & 18 & 5.0 \\
\hline MCRJ & $1,3,26,3 \mathrm{ka}, 11,30,10,14 \mathrm{a}$ & 3 & 5.3 & 2 & 3.4 & 0 & 0 & 0 & 0 & 5 & 1.4 \\
\hline MDBJ & $1,3,24,10,14 \mathrm{a}$ & 0 & 0 & 0 & 0 & 2 & 1.1 & 3 & 5.3 & 5 & 1.4 \\
\hline MDGJ & $1,3,24,11,10,14 a$ & 0 & 0 & 1 & 1.7 & 0 & 0 & 0 & 0 & 1 & 0.3 \\
\hline MDMJ & $1,3,24,3 \mathrm{ka}, 30,10,14 \mathrm{a}$ & 0 & 0 & 0 & 0 & 1 & 0.5 & 0 & 0 & 1 & 0.3 \\
\hline MDQJ & $1,3,24,3 \mathrm{ka}, 11,10,14 \mathrm{a}$ & 0 & 0 & 1 & 1.7 & 2 & 1.1 & 0 & 0 & 3 & 0.8 \\
\hline MDRJ & $1,3,24,3 \mathrm{ka}, 11,30,10,14 \mathrm{a}$ & 11 & 19.3 & 8 & 13.8 & 21 & 11.1 & 2 & 3.5 & 42 & 11.6 \\
\hline MGBJ & $1,3,16,10,14 \mathrm{a}$ & 0 & 0 & 0 & 0 & 1 & 0.5 & 0 & 0 & 1 & 0.3 \\
\hline MGDJ & $1,3,16,17,10,14 \mathrm{a}$ & 0 & 0 & 0 & 0 & 1 & 0.5 & 0 & 0 & 1 & 0.3 \\
\hline MJBJ & $1,3,16,24,10,14 a$ & 0 & 0 & 1 & 1.7 & 1 & 0.5 & 0 & 0 & 2 & 0.6 \\
\hline MPRJ & $1,3,9,24,26,3 \mathrm{ka}, 11,30,10,14 \mathrm{a}$ & 1 & 1.8 & 0 & 0 & 0 & 0 & 0 & 0 & 1 & 0.3 \\
\hline NBBQ & $1,2 \mathrm{c}, \mathrm{B}, 10$ & 0 & 0 & 1 & 1.7 & 0 & 0 & 0 & 0 & 1 & 0.3 \\
\hline NBBR & $1,2 \mathrm{c}, \mathrm{B}, 10,18$ & 0 & 0 & 0 & 0 & 0 & 0 & 13 & 22.8 & 13 & 3.6 \\
\hline PBDB & $1,2 \mathrm{c}, 3,17$ & 0 & 0 & 0 & 0 & 0 & 0 & 17 & 29.8 & 17 & 4.7 \\
\hline PBDS & $1,2 \mathrm{c}, 3,17, \mathrm{~B}, 10,14 \mathrm{a}$ & 1 & 1.8 & 0 & 0 & 0 & 0 & 0 & 0 & 1 & 0.3 \\
\hline PBLQ & $1,2 \mathrm{c}, 3,3 \mathrm{ka}, \mathrm{B}, 10$ & 6 & 10.5 & 17 & 29.3 & 0 & 0 & 0 & 0 & 23 & 6.4 \\
\hline PBMQ & $1,2 \mathrm{c}, 3,3 \mathrm{ka}, 30, \mathrm{~B}, 10$ & 0 & 0 & 1 & 1.7 & 0 & 0 & 0 & 0 & 1 & 0.3 \\
\hline PBPD & $1,2 \mathrm{c}, 3,3 \mathrm{ka}, 17,30,14 \mathrm{a}$ & 0 & 0 & 0 & 0 & 0 & 0 & 1 & 1.8 & 1 & 0.3 \\
\hline PBRJ & $1,2 \mathrm{c}, 3,3 \mathrm{ka}, 11,30,10,14 \mathrm{a}$ & 0 & 0 & 0 & 0 & 0 & 0 & 1 & 1.8 & 1 & 0.3 \\
\hline PBRN & $1,2 \mathrm{c}, 3,3 \mathrm{ka}, 11,30, \mathrm{~B}, 14 \mathrm{a}$ & 1 & 1.8 & 0 & 0 & 0 & 0 & 0 & 0 & 1 & 0.3 \\
\hline PBRQ & $1,2 \mathrm{c}, 3,3 \mathrm{ka}, 11,30, \mathrm{~B}, 10$ & 0 & 0 & 3 & 5.2 & 0 & 0 & 0 & 0 & 3 & 0.8 \\
\hline PBRR & $1,2 \mathrm{c}, 3,3 \mathrm{ka}, 11,30, \mathrm{~B}, 10,18$ & 0 & 0 & 1 & 1.7 & 0 & 0 & 0 & 0 & 1 & 0.3 \\
\hline TBBJ & $1,2 \mathrm{a}, 2 \mathrm{c}, 3,10,14 \mathrm{a}$ & 0 & 0 & 0 & 0 & 1 & 0.5 & 0 & 0 & 1 & 0.3 \\
\hline TDBJ & $1,2 \mathrm{a}, 2 \mathrm{c}, 3,24,10,14 \mathrm{a}$ & 1 & 1.8 & 0 & 0 & 0 & 0 & 0 & 0 & 1 & 0.3 \\
\hline TDGJ & $1,2 \mathrm{a}, 2 \mathrm{c}, 3,24,11,10,14 \mathrm{a}$ & 0 & 0 & 0 & 0 & 2 & 1.1 & 0 & 0 & 2 & 0.6 \\
\hline TFGJ & $1,2 \mathrm{a}, 2 \mathrm{c}, 3,24,26,11,10,14 \mathrm{a}$ & 0 & 0 & 1 & 1.7 & 0 & 0 & 0 & 0 & 1 & 0.3 \\
\hline TFLJ & $1,2 \mathrm{a}, 2 \mathrm{c}, 3,24,26,3 \mathrm{ka}, 10,14 \mathrm{a}$ & 0 & 0 & 1 & 1.7 & 0 & 0 & 0 & 0 & 1 & 0.3 \\
\hline TGBJ & $1,2 \mathrm{a}, 2 \mathrm{c}, 3,16,10,14 \mathrm{a}$ & 0 & 0 & 0 & 0 & 17 & 8.9 & 0 & 0 & 17 & 4.7 \\
\hline THBJ & $1,2 \mathrm{a}, 2 \mathrm{c}, 3,16,26,10,14 \mathrm{a}$ & 0 & 0 & 0 & 0 & 8 & 4.2 & 0 & 0 & 8 & 2.2 \\
\hline TJBJ & $1,2 \mathrm{a}, 2 \mathrm{c}, 3,16,24,10,14 \mathrm{a}$ & 6 & 10.5 & 0 & 0 & 0 & 0 & 0 & 0 & 6 & 1.7 \\
\hline TKBJ & $1,2 \mathrm{a}, 2 \mathrm{c}, 3,16,24,26,10,14 \mathrm{a}$ & 2 & 3.5 & 2 & 3.4 & 3 & 1.6 & 0 & 0 & 7 & 1.9 \\
\hline TLGK & $1,2 \mathrm{a}, 2 \mathrm{c}, 3,9,11,10,14 \mathrm{a}, 18$ & 0 & 0 & 2 & 3.4 & 0 & 0 & 0 & 0 & 2 & 0.6 \\
\hline Total & & 57 & & 58 & & 190 & & 57 & & 362 & \\
\hline
\end{tabular}

isolated previously from Manitoba and Saskatchewan $(11,12)$ and the southern plains of the United States. These phenotypes may have migrated to Quebec from either of these two regions. PBLQ has been a common phenotype in previous years in Quebec $(11,12)$. This phenotype is usually found only in Quebec or Ontario and may be associated with winter wheats.

In Ontario, 21 virulence phenotypes were identified with PBLQ (29.3\%), MDRJ (13.8\%), and MBGJ (6.9\%), accounting for $50 \%$ of the 58 isolates. PBLQ was also common in 1996 at $25 \%$ of isolates from Ontario, while MDRJ was not collected in 1996 from Ontario (11). MBGJ has been identified in most previous years from Ontario (11) and may also be associated with winter wheats.

In Manitoba and Saskatchewan, over $95 \%$ of isolates had virulence to $L r l, L r 3$,
Lr10, and Lr14a (Table 1). None of the isolates had virulence to $L r 9$, and only one isolate had virulence to $\operatorname{Lr} 18$. Virulence to Lr18 has been rare in this region $(11,12)$. Virulence to the other resistance genes ranged between 16.3 to $47.4 \%$. Virulence to Lrl6 increased from $5.9 \%$ in 1996 to $16.3 \%$ in 1997. Many recently released spring wheat cultivars grown in this region (AC Karma, AC Majestic, AC Splendor, AC Barrie, and AC Domain) have Lrl6 in addition to adult plant resistance genes. Leaf rust severities on these cultivars may increase in future years if isolates with virulence to this gene continue to increase. The frequency of isolates $(46.8 \%)$ with virulence to $\operatorname{Lr} 17$ changed relatively little from 1996 levels (11). Winter wheats with Lrl7 grown in the United States selected isolates with virulence to this gene starting in 1996.
In Manitoba and Saskatchewan, $19 P$. triticina virulence phenotypes were identified in 1997 (Table 2). Phenotypes MBDS (38.4\%), MBRJ (20.0\%), and MDRJ (11.1\%) comprised $69.5 \%$ of the 190 isolates tested for virulence. MBDS, with virulence to $\operatorname{Lr} 17$, was also the most common phenotype in Manitoba in 1996 (11) Phenotypes MBRJ and MDRJ were also common in 1996. Virulence to Lrl6 was found in six phenotypes, the most common TGBJ was at $8.9 \%$ of isolates.

In Alberta, over $95 \%$ of isolates had virulence to $\mathrm{Lrl}$ (Table 1). None of the isolates had virulence to $L r 2 a, L r 9$, or Lr16. Virulence to other resistance genes ranged from 3.5 to $77.2 \%$. Eleven virulence phenotypes were found in 1997 (Table 2). Phenotypes PBDB (29.8\%), NBBR (22.8\%), and MBGJ (14\%) comprised $66.6 \%$ of the 57 isolates tested. Iso- 
Table 3. Infection types ${ }^{\mathrm{a}}$ on adult plants of isogenic Thatcher lines with resistance genes $\operatorname{Lr} 12, \operatorname{Lr} 13$, Lr34, and Lr13,34, and Thatcher of representative Puccinia triticina isolates collected from Canada in 1997

\begin{tabular}{|c|c|c|c|c|c|}
\hline Isolate & TcLr12 & TcLr13 & TcLr34 & TcLr13, 34 & Thatcher \\
\hline CCDJ $215-1^{b}$ & 4 & 4 & 23 & $23(\text { few })^{c}$ & 4 \\
\hline FCMT 252-2 & 4 & ; & 23 (few) & 0 & 4 \\
\hline KFBJ 64-1 & 4 & ;1 & 23 (few) & 0 & 4 \\
\hline KDMT 46-1 & 2 & $22+$ & 23 & 0 & 4 \\
\hline LCBK 254-1 & $22+$ & ;1- & 23 (few) & 0 & 4 \\
\hline MBDJ 59-1 & 4 & $22+$ & 23 (few) & 0 & 4 \\
\hline MBDS $11-1$ & 4 & 4 & 23 (few) & 23 (few) & 4 \\
\hline MBDS 57-1 & 4 & 4 & 23 (few) & 23 (few) & 4 \\
\hline MBDS 32-1 & 4 & 4 & 23 (few) & 23 (few) & 4 \\
\hline MBDS 9-1 & 4 & 4 & 23 (few) & 23 (few) & 4 \\
\hline MBDS $141-1$ & 4 & 4 & 23 (few) & 23 (few) & 4 \\
\hline MBRJ 60-1 & 1 & 4 & 23 (few) & 23 (few) & 4 \\
\hline MBRJ 236-1 & $2-$ & 4 & 23 (few) & 23 (few) & 4 \\
\hline MBRJ 132-2 & $; 1$ & 4 & 23 (few) & 23 (few) & 4 \\
\hline MBRJ 56-1 & $; 1$ & 4 & 23 (few) & 23 (few) & 4 \\
\hline MBRJ 2-1 & 4 & $23+$ & 23 (few) & 0 & 4 \\
\hline MCDS $17-1$ & 4 & 4 & 23 (few) & 23 (few) & 4 \\
\hline MCDS $125-2$ & 4 & 4 & 23 (few) & 23 (few) & 4 \\
\hline MCDS 90-2 & 4 & 4 & 23 (few) & 23 (few) & 4 \\
\hline MDQJ $130-2$ & 4 & $; 1$ & 23 (few) & 0 & 4 \\
\hline MDRJ 39-1 & $33+$ & $; 2+3$ & 23 (few) & 0 & 4 \\
\hline MDRJ 4-1 & 4 & $; 2+3$ & 23 (few) & 0 & 4 \\
\hline MDRJ 133-2 & 4 & $; 2$ & 23 (few) & 0 & 4 \\
\hline MJBJ 116-1 & $; 1$ & ; & 23 (few) & 0 & $33+$ \\
\hline PBDS 258-1 & 4 & 4 & 3 & ;2 (few) & 4 \\
\hline PBLN 232-1 & 4 & 4 & $33+($ few $)$ & 23 (few) & 4 \\
\hline TFGJ 222-2 & 4 & ; & 23 (few) & 0 & 4 \\
\hline TGBJ 94-1 & 4 & 4 & 23 (few) & 23 (few) & 4 \\
\hline TGBJ 62-1 & 4 & 4 & 23 (few) & 23 (few) & 4 \\
\hline TGBJ 124-1 & 4 & 4 & 23 (few) & 23 (few) & 4 \\
\hline THBJ 147-2 & 4 & 4 & 23 (few) & 23 (few) & 4 \\
\hline TKBJ $145-1$ & 4 & 4 & 23 (few) & 23 (few) & 4 \\
\hline TLBJ 312-1 & $; 1$ & 4 & 23 (few) & 23 (few) & 4 \\
\hline
\end{tabular}

a Infection type scale: $0=$ no necrosis or uredinia, $;=$ small hypersensitive flecks, $1=$ small uredinia surrounded by necrosis, 2 = moderate size uredinia surrounded by chlorosis, $3=$ moderate size uredinia without chlorosis, $4=$ large uredinia without chlorosis, $+=$ larger uredinia than expected for the infection type, $-=$ smaller uredinia than expected for the infection type, $\mathrm{n}=$ prominent necrosis, $\mathrm{c}=$ prominent chlorosis.

b Single pustule isolate number.

c Indicates fewer uredinia than the susceptible check Thatcher.

lates with phenotype PBD- comprised 50\% of the Alberta population in 1996 (11), while phenotypes NBBR and MBGJ were not found in Alberta in 1996. Phenotypes PBDand NBB- have previously been collected from the intermountain region of British Columbia and may have migrated to southern Alberta from this region in 1997.

Adult plant virulence. Thirty-three isolates comprising 18 virulence phenotypes were tested for virulence to plants with resistance genes $\operatorname{Lr} 12, \operatorname{Lr} 13, \operatorname{Lr} 34$, and $L r 13,34$, in addition to the recurrent parent Thatcher, which has $L r 22 b$. All isolates had high infection type (IT) on Thatcher. Eight isolates had low IT to the Thatcher line with $\operatorname{Lr} 12$ (Table 3). Twelve isolates had low IT to Lr13. Isolates within virulence phenotype MBRJ differed for virulence to $\operatorname{Lrl1}$ and $\operatorname{Lrl3}$. All isolates had IT of 23, with fewer pustules on plants with $L r 34$ compared with the susceptible check Thatcher. All isolates that had low IT to Lrl3 had IT 0; on plants with Lr13,34 (Table 3). Isolate PBDS 258-1 had IT 4 to $L r 13$, but had IT ;2 (with few pustules) to $\operatorname{Lr} 13,34$. This may be an example of interaction between two resistance genes conditioning a lower IT than expected based on the IT of the individual genes. Genes Lr13 and Lr34 have been noted previously (6) to interact with other resistance genes to condition enhanced resistance to leaf rust.

\section{ACKNOWLEDGMENTS}

I thank P. Seto-Goh and C. Sargent for conducting the technical aspects of the survey, and the cooperators for the care of the rust nurseries and for sending samples of leaf rust.

\section{LITERATURE CITED}

1. Anikister, Y., Bushnell, W. R., Eilam, T., Manisterski, J., and Roelfs, A. P. 1997. Puc- cinia recondita causing leaf rust on cultivated wheats, wild wheats, and rye. Can. J. Bot 75:2082-2096.

2. Basile, R. 1957. A diagnostic key for the identification of physiologic races of Puccinia rubigo-vera tritici grouped according to a unified numeration scheme. Plant Dis. Rep. 41:508-511.

3. Burdon, J. J., Luig, N. H., and Marshall, D. R. 1983. Isozyme uniformity and virulence variation in Puccinia graminis f. sp. tritici and $P$. recondita tritici in Australia. Aust. J. Biol. Sci. 35:231-238.

4. Burdon, J. J., and Roelfs, A. P. 1985. Isozyme and virulence variation in asexually reproducing populations of Puccinia graminis and $P$. recondita on wheat. Phytopathology 75:907-913.

5. Dyck, P. L., and Samborski, D. J. 1968. Genetics of resistance to leaf rust in the common wheat varieties Webster, Loros, Brevit, Carina, Malakof, and Centenario. Can. J. Genet. Cytol. 10:7-17.

6. German, S. E., and Kolmer, J. A. 1992. Effect of gene Lr34 in the enhancement of resistance to leaf rust of wheat. Theor. Appl. Genet. 84:97-195.

7. Johnson, C. O., and Mains, E. B. 1932 Studies on physiologic specialization in Puccinia triticina. Tech. Bull. U.S. Dep. Agric. 313.

8. Kolmer, J. A. 1989. Virulence and race dynamics of Puccinia recondita f. sp. tritici in Canada during 1956-1987. Phytopathology 79:349-356.

9. Kolmer, J. A. 1991. Evolution of distinct populations of Puccinia recondita f. sp. tritici in Canada. Phytopathology 81:316-322.

10. Kolmer, J. A. 1997. Virulence in Puccinia recondita $\mathrm{f}$. $\mathrm{sp}$. tritici isolates from Canada to genes for adult-plant resistance to wheat leaf rust. Plant Dis. 81:267-271.

11. Kolmer, J. A. Physiological specialization of Puccinia recondita f. sp. tritici in Canada in 1996. Can. J. Plant Pathol. In press.

12. Kolmer, J. A., and Liu, J. Q. 1997. Physiological specialization of Puccinia recondita $\mathrm{f}$ sp. tritici in Canada in 1995. Can. J. Plant Pathol. 19:166-170.

13. Kolmer, J. A., Liu, J. Q., and Sies, M. 1995. Virulence and molecular polymorphism in Puccinia recondita $\mathrm{f}$. $\mathrm{sp}$. tritici in Canada. Phytopathology 85:276-285.

14. Liug, N. H., Burdon, J. J., and Hawthorn, M. W. 1985. An exotic strain of Puccinia recondita tritici in New Zealand. Can. J. Plant Pathol. 7:173-176.

15. Long, D. L., and Kolmer, J. A. 1989. A North American system of nomenclature for Puccinia recondita f. sp. tritici. Phytopathology 79:525-529.

16. Mains, E. B., and Jackson, H. S. 1926. Physiologic specialization in the leaf rust of wheat Puccinia triticina Erikss. Phytopathology 16:89-120.

17. Park, R. F., Burdon, J. J., and McIntosh, R. A. 1995. Studies on the origin, spread, and evolution of an important group of Puccinia recondita f. sp. tritici pathotypes in Australasia. Eur. J. Plant Pathol. 101:613622.

18. Samborski, D. J., and Dyck, P. L. 1968. Inheritance of virulence in wheat leaf rust on the standard differential wheat varieties. Can. J. Genet. Cytol. 10:24-32. 